\title{
Structure of Al-targets Used for PVD Coating in Jewellery
}

Pavel Kejzlar, Zuzana Andrsova, Martin Švec

Laboratory of Analytical Methods, Department of the Preparation and Analysis of Nanostructures, Institute for Nanomaterials, Advanced Technologies and Innovation, Technical Univertsity of Liberec, Studenstka 1402/2, 46117 Liberec, Czech Republic. E-mail: pavel.kejzlar@tul.cz, zuzana.andrsova@email.cz, martin.svec@tul.cz

Aluminium, chromium, silver and other metal targets are often used for glass crystal coating in jewellery. The structure of targets strongly influences the quality of coating which leads to differences in their optical properties. The targets from two manufacturers were examined using scanning electron microscopy combined with EBSD with a goal to identify possible metallographic cause of defects arising on glass jewels.

Keywords: Aluminium, Structure, PVD, Thin layers, EBSD

\section{Acknowledgement}

The results of this project LO1201 were obtained with co-funding from the Ministry of Education, Youth and Sports as part of targeted support from the "Národni program udržitelnosti I" programme.

\section{References}

[1] MARTIN, P. M. (2009). Handbook of deposition technologies for films and coatings: science, applications and technology. 3rd ed. Norwich, N.Y: William Andrew. ISBN 9780815520313.

[2] HECHT, E., ZAJĄC, A. (1987). Optics. 2nd ed. Reading, Mass.: Addison-Wesley Pub. Co., X, 676 p. ISBN 020111609x.

[3] IDEX OPTICS AND PHOTONICS. Technical Guide: Optical Coating and Materials [online]. [cit. 2015-08-18]. Available from: http://marketplace.idexop.com/store/SupportDocuments/1-Optical\%20Coating\%20and\%20Materials.pdf

[4] MACLEOD, H. (1969). Thin-film optical filters. London: Adam Hilger Ltd., XI, 332 p. ISBN 0852740913.

[5] CVI Melles Griot: 5 Optical Coatings. Optical Coating - CVI Melles Griot - PDF Catalogue| Technical Documentation | Brochure [online]. 2015 [cit. 2015-08-18]. Dostupné z: http://pdf.directindustry.com/pdf/cvi-mellesgriot/optical-coating/12567-266749.html

[6] Edmund Optics: An Introduction to Optical Coatings [online]. 2012 [cit. 2015-08-18]. Dostupné z: http://www.edmundoptics.com/technical-resources-center/optics/an-introduction-to-optical-coatings/

[7] Edmund Optics: Metallic Mirror Coatings [online]. 2012 [cit. 2015-08-18]. Dostupné z: http://www.edmundoptics.com/technical-resources-center/optics/metallic-mirror-coatings/

[8] JAKSH, H. (2008). Strain related contrast mechanisms in crystaline materials. In: EMC 2008: 14th European Micros-copy Congress 1-5 September 2008, Aachen Germany; Volume 1: Instrumentation and methods. 1st ed. New York: Springer. ISBN 9783540851547

[9] KEJZLAR, P., ŠVEC M., MACAJOVÁ E. (2014). The Usage of Backscattered Electrons in Scanning Electron Microscopy. In: Manufacturing Technology, Vol. 14, No. 3, pp. 333-336.

[10] WRIGHT, S. I., NOWELL, M. M., FIELD, D. P. (2011). A Review of Strain Analysis Using Electron Backscatter Diffraction. In: Microscopy and Microanalysis [online]. 17(03): pp. 316-329 [cit. 2015-08-03]. DOI: 10.1017/s1431927611000055. 